\title{
Understanding NATO in the 21st Century. Alliance Strategies, Security and Global Governance. Edited by Graeme P. Herd and John Kriendler. New York: Routledge, 2013.
}

Serena Simoni

Samford University

Follow this and additional works at: https://digitalcommons.usf.edu/jss

pp. $124-126$

\section{Recommended Citation}

Simoni, Serena. "Understanding NATO in the 21st Century. Alliance Strategies, Security and Global Governance. Edited by Graeme P. Herd and John Kriendler. New York: Routledge, 2013.." Journal of Strategic Security 6, no. 3 (2013) : 124-126.

DOI: http://dx.doi.org/10.5038/1944-0472.6.3.12

Available at: https://digitalcommons.usf.edu/jss/vol6/iss3/12

This Book Review is brought to you for free and open access by the Open Access Journals at Digital Commons @ University of South Florida. It has been accepted for inclusion in Journal of Strategic Security by an authorized editor of Digital Commons @ University of South Florida. For more information, please contact digitalcommons@usf.edu. 


\section{Understanding NATO in the 21st Century. Alliance Strategies, Security and Global Governance. Edited by Graeme P. Herd and John Kriendler. New York: Routledge, 2013.}


Understanding NATO in the 21st Century. Alliance strategies, security and global governance. Edited by Graeme P. Herd and John Kriendler. New York: Routledge, 2013. ISBN 978-0415-43633-5 (hardcover). 259pp, \$135.00.

In a time of financial meltdown and decreasing defense budgets, one could ask: who needs NATO? Once upon a time there was a simple answer. "NATO," said General Lord Ismay, its first Secretary General, was "to keep the Russians out, the Americans in, and the Germans down." In the post-Cold War world, however, the answer is much more nuanced. This is the starting point of this compelling and thought-provoking book.

This edited book brings together experts on NATO, many of whom have a direct knowledge of the organization since, at different points in their lives, they have worked for the Alliance. The contributors also mirror the different perspectives about the future of the Alliance. Indeed, in academia there is no consensus on the resilience of NATO to the changing security context. The editors, Graeme P. Herd and John Kriendler, argue that there are several reasons for this: spending shortages on both sides of the Atlantic, national caveats (short- vs. long-term operations and investments) and generational change (i.e., the fading off of Atlanticist policymakers). Instead of focusing on Europe-the historic American ally within NATO which they argue is a region of declining importance with a bad perception of U.S. competence and credibility - the contributors analyze the strategic challenges emanating from the Pacific region. They justify this choice in light of the acceptance that the 21st century is a 'U.S. Pacific Century' and that President Obama is the first 'Pacific President,' perhaps demonstrating that not just Atlanticist policymakers, but also Atlanticist practitioners are 'aging out'.

The main question the book tries to answer is: will NATO survive the challenges of the evolving security environment? Through a realist theoretical lens, the authors put forward two different scenarios developing from two hypothetical structural changes. That is, if the international system shifts from unipolar to bipolar the strategic environment can generate Sino-U.S. rivalry. The other scenario is the rise of a multipolar cooperative world system in which China is only one of the emerging new powers (alongside other BRICS and Next-11 states). The editors suggest that within the first hypothetical security context, NATO could counterbalance China by consolidating existing and/or creating new regional partnerships. However, if the alternative scenario develops, they claim, NATO could become the indispensable collective security organization which delivers "multinational solutions to global problems" (p. 219).

The book can be divided into three parts. Part one, chapters 2-6, addresses NATO's institutional evolution and its outreach to former adversaries. Part two, chapters 7-9, grapples with NATO's operational future. Part three, chapters 10-12, focuses on new security threats and possible responses.

Chapters 2, 3, and 4 offer a good background overview of the evolution of NATO by presenting both a European and a U.S. perspective on the organization. Graeme P. Herd, John Kriendler and Kalus Wittmann's chapter 2 about the origin and evolution of NATO presents the reader with an excellent summary of the key milestones in the adaptation of NATO to new security contexts. Thus, they constitute an excellent starting point for a discussion in the next chapters about the direction and the scope of NATO's potential transformation in the 21st century. In chapter 5, 
Herd reminds the reader that one of the enduring questions with regards to the current globally interconnected world has been: "how far should NATO partnerships extend and what countries should be included?" (p. 76). P"how far should NATO partnerships extend and what countries should be included?" (ts. Thus, they constitute an excellent starti. However, Herd claims partnerships have been "one of NATO's most successful post-Cold War policies" (p. 67). His chapter makes a first important pragmatic suggestion for NATO's future success. That is, the Alliance should continue seeking partners while having a "fluid and flexible" approach (p. 81). Indeed, in a world system that has no real teeth NATO is perhaps the only institution that could fill in the gaps between law and order.

The next three chapters, 7-9, ask a difficult question: what operations should NATO run? In chapter 7, Thierry Tardy highlights the shortcomings that NATO is facing. He sharply observes that one important obstacle to the NATO conception of Comprehensive Approach (i.e., the idea of civil-military cooperation) is that allies such as France, Belgium, Germany, or Spain perceive the Alliance primarily as a military institution. This, Tardy argues, hinders the development of civilian capabilities and/or involvement of NATO in development activities. In addition, the negative experiences of Afghanistan and Libya, Tardy anticipates, will lead to "a return to more traditional peace consolidation missions" (p. 112). Accordingly, his critique is followed by Julian Lindley-French's recognition, in chapter 8, of the need for "real unity of effort and purpose" to be established at the beginning of any NATO campaign. The approach NATO should have, he claims, should be "truly multinational" and there should be a "willingness to share political and military risk" (p. 121).

Examining new possible threats, the last part of the book, delves into cyber security, missile defense and energy security. Jeffrey Hunker discusses the very current problem of deterrence against cyber attacks and highlights the difficulties in dealing with it. First, he claims there is a need for characterizing what constitutes a threat in cyberspace. Second, there needs to be consensus among Alliance members and/or interests in deterring. Third, even if the first two difficulties are overcome, there would still be both technical and organizational problems. For example, how and under what circumstances NATO's own networks can be secured? NATO's networks depend on interconnected networks, which are not under its control. This makes NATO's cyber deterrence highly labor-intensive.

The last two chapters focus on two additional issues: missile defense and energy security. While missile defense is by all means not a new issue, Gustav Lindstrom in his chapter stresses how there is no single vision about the evolution of it and indicates three key issues that are to be addressed: cooperation between NATO and Russia, the extension of the Phased Adaptive Approach (AAP) to regions beyond Europe, and finally, the missile threat evolution. Finally, Phillip Cornell, in chapter 10, offers good background insights into energy security vis-a-vis NATO and suggests that reducing dependence on foreign imports (i.e. fossil fuels) will have a positive impact on the security environment.

As a whole, this book offers a comprehensive approach to the future of NATO in the 21 st century, and its focus on the Alliance's institutional evolution and operational future is an important contribution. Theoretically, the book seems to rely on Realism and the distribution of power, seemingly unaware that Constructivism could be a better suited approach in 
"understanding" change (and/or evolution). Yet, the tripartite structure of each chapter in an historical examination, identification of the issue and possible scenarios makes it excellent reading for undergraduate and graduate students. Lastly, this work demonstrates how practitioners of international relations can go beyond answering the "how to" question and engage scholars of IR in a fruitful dialogue.

Serena Simoni, Department of Political Science, Samford University 